renders certain persons susceptible to pollen, nothing is known with certainty. It has been suggested that the affected persons may possess a specific proteolytic ferment which, acting on pollen protein, liberates a poison which is the active agent. The predisposition has been regarded as allied to anaphylaxis-the state of hypersensitivity, which can be induced especially in guineapigs by a sub-lethal dose of a protein of some kind.

Hay-fever predisposition, however, differs fundamentally from true anaphylaxis. The anaphylactic state can be transmitted passively to a normal animal by means of the serum of an animal rendered actively anaphylactic. This is not so with hay fever. Dunbar injected the blood serum of hay-fever persons into guinea-pigs, and twenty-four hours later injected the animals intravenously with rye-pollen protein. No positive results were obtained. Further, normal persons never develop hay fever after the subcutaneous injection of pollen protein. Dunbar injected a normal person with quantities of pollen protein far in excess of what he could have received normally, but this individual was able to take long walks through meadows in full flower, with impunity. A normal person has not the capacity of reacting to pollen protein, nor can he be made to develop this power experimentally. It may be said, therefore, that whatever is the nature of pollen idiosyncrasy, it is not to be ranged alongside the true anaphylactic state. It is allied to those idiosyncrasies which occur in certain persons who develop asthma or catarrhal symptoms from exposure to the secretions or excretions of horses, dogs, cats, goats, rabbits, guinea-pigs, or to such substances as silk, or food-stuffs like white of egg, or certain drugs.

From the great mass of persons who have the pollen idiosyncrasy, and the "annual torment," as Blackley called it, which they undergo, it is not surprising that many different treatments have been recommended.
If the hay-fever patient could keep away from pollen, naturally he would not suffer from the disease, Thousands of persons find relief annually at the seaside or on islands or barren districts. The German Hay Fever Association used to recommend Heligoland. In the United States, Fire Island on the Atlantic side of Long Island has long enjoyed a reputation as a suitable refuge for hay-fever sufferers. Blackley in England spoke highly of Lundy Island and some of the islands in the Hebrides. For the great majority of patients such luxuries are manifestly impossible.

From the vast number of methods of treatment praised at one time or another, only two are worthy of consideration. Dunbar recommended the serum called Pollantin, prepared by inoculating horses with repeated doses of pollen protein. This is used either in the liquid or dry state for local application to the nose before the onset of symptoms. The main objection to this treatment, which may be most successful in certain cases, is the temporary character of the relief afforded. The other method, erroneously called desensitisation, is the active immunisation of the patient himself by pollen protein introduced by Noon and Freeman. For its success accurate diagnosis of the specific pollen idiosyncrasy is necessary in the first place, the production of strong protein solutions in the second place, and pre-seasonal inoculation in the third place. As the immunity is not durable the treatment must be annual. By this method Freeman (r9r4) recorded 30 per cent. of complete successes and no improvement in II per cent. Between I916 and I920 Cooke and Vander Veer injected I774 patients with complete success in 25 per cent. and no success in ro per cent. The recent results of Bernton (I923) are of the same order. It is probable that the state of insusceptibility lasts only for a few weeks, when the patient again manifests his idiosyncrasy unaltered.

W. B.

\title{
The Tercentenary of Blaise Pascal.
}

\section{By Prof. H. Wildon CARr.}

$\mathrm{N}^{0}$ one can read the story of Pascal's life without amazement at the greatness of his genius and sadness at the mode in which it found expression. To Voltaire in the eighteenth century he is a "fou sublime, né un siècle trop tôt." To Chateaubriand in the early nineteenth century he is " cet effrayant génie, qui, à cet âge où les autres hommes commencent à peine de naître, ayant achevé de parcourir le cercle des sciences humaines, s'aperçut de leur néant et tourna ses pensées vers la religion." He lived at the beginning of the brilliant leadership of France in the intellectual development of Europe. In his short life he did notable work in mathematics and physics, and above all (to continue the quotation from Chateaubriand), "toujours infirme et souffrant, fixa la langue que parlèrent Bossuet et Racine, donna le modèle de la plus parfaite plaisanterie, comme du raisonnement le plus fort."

To appreciate the greatness of Pascal and to discern the leading motive in his wonderful activity, it is necessary to enter sympathetically into the spirit of the age in which he lived, and particularly to under- stand the nature of the religious influence which peculiarly affected him from infancy to maturity.

The outward circumstances of his life may be recorded quite briefly. He was born at Clermont in the Auvergne on June I9, I623. His father, Étienne Pascal; was King's Councillor and Magistrate, president of the Cour des Aides. Blaise had two sisters, Gilberte, three years older, and Jacqueline, two years younger than himself. Their mother died when Blaise was three years old. In $x 6_{31}$ the father retired and settled with his family in Paris for the sake of their education. In 1638 he had managed unfortunately to incur the displeasure of Cardinal Richelieu, and, having good reason to fear a lettre de cachet, had to go into hiding. He returned home, however, risking arrest, when he heard that his dearly loved daughter Jacqueline was suffering from small-pox, and he remained constantly with her until her recovery. The following year there was brought about a reconciliation with the Cardinal, and shortly after he received the appointment "Intendant pour les tailles de la généralité " at Rouen, to which city the family then went to live. In 1648 the

$$
\text { NO. } 2798 \text {, VOL. I I I] }
$$


"Intendants" were suppressed by Mazarin, and the Pascals returned to Paris. The following year they went back to their native Clermont; where Gilberte, who had married her cousin, Florin Périer, was already settled... In $165 \mathrm{I}$ the father died. Blaise, devoted to his sister Jacqueline, had hoped that after the father's death she would continue to make her home with him, but she had already formed her resolution to enter the religious life, and would not be dissuaded from taking immediately the austere vow at the convent of Port Royal.

The four following years are described by Blaise as his "mondaine" period. He sought distraction in travel and society, but in 1655 , after a mental crisis : which is described as his second conversion, he decided to retire and devote himself entirely to religion. From 1658 till his death in 1662 ; although not bedridden or incapacitated from attending to his ordinary wants, he was so weak and in such continual pain that he could do no consecutive work. Jacqueline died in I66r. Blaise in his last illness was nursed by Gilberte. He died in her house. When the end was approaching the doctors attending him were assuring him that there was no danger, and refused to call in the priest. Pascal was in anguish lest he should die without the sacrament, but Gilberte acted on her own initiative just in time. She lived to be sixty-seven, and had five children. She wrote the life of her brother, and also a life of her sister Jacqueline.

Blaise Pascal was educated by his father, and had no other tutor. He never entered the university. All his acquaintance with the intellectual movements of his age, with its science, its philosophy, its religion, was derived directly from his father and conversation with his father's friends. On the other hand, at his father's house he met the most distinguished mathematicians and theologians of the time. Étienne Pascal did not merely supervise his son's education; he undertook it alone and unaided in order to follow out a predetermined method, which reminds us, alike in its conception and in its consequences, of the analogous case of the father of John Stuart Mill. One part of the scheme was to concentrate the boy's mind during his earliest years on perfecting his knowledge of his own language. His lessons were limited to the grammar and syntax of his native French, and the teaching even of Latin was deferred until this was acquired, in the expectation that the new task would then be comparatively easy. The other part of the scheme was to defer mathematics, indeed to forbid the study of it, until the acquirement of languages was perfect. The reason of this is curious. The father was not only himself learned in the mathematical sciences, but also had given his daughter Gilberte thorough instruction in them, yet he feared for his son that they. would prove of such absorbing interest that he would be distracted from the study of languages. When the lad was twelve, however, the father discovered that he had acquired, apparently surreptitiously, an acquaintance with geometry which amounted to precocity. $\mathrm{He}$ was found one day demonstrating for himself with barres et ronds the thirty-second proposition of Euclid's first book. We are told that after this he was allowed to read Euclid, but only in his recreation hours.

$$
\text { NO. } 2798, \text {. VOL. I I I] }
$$

Not less powerful than the parental influence was that of his sisters. For their education also the father had original ideas. He did not himself undertake it, but they were educated by a man as men. Their tutor was a Monsieur de Mondory, in favour with the Cardinal and the Court. Facqueline was an extraordinarily precocious child. She was a very pretty girl before the small-pox destroyed her beauty. She wrote verses from the time of her early childhood, and when fourteen composed a comedy in five acts. She was deeply religious. One of her poems is a hymn of gratitude to God for her recovery, and she describes the scars left by the disease as the impressions of God's seal. She no doubt regarded this illness as a sign of her call to the religious life. Soon after her entry to Port Royal she was appointed sub-prioress, and she consulted her superior as to whether she should cultivate her talent for poetry. The reply of Mère Agnes, Arnauld's sister, is pathetic. "C'est un talent dont Dieu ne vous demandera point compte : il faut l'ensevelir." She signed the formulary imposed on Port Royal condemning the Jansenist doctrine under extreme pressure, though she struggled against it and wished to resist. "Je sais bien," she wrote to Dr. Arnauld, "que ce n'est pas à des filles à défendre la vérité, quoique l'on peut dire par une triste rencontre, que, puisque les évêques ont des courages de filles, les filles doivent avoir des courages d'évêques." Arnauld insisted, however, and the grief hastened her death.

To understand the religious fervour of the Pascal family we must also enter sympathetically into the spirit of the age. The seventeenth century shows in all its philosophy, and even we may say in its science, the influence of a deep personal interest in the problem of the relation of the individual mind to God. The reforming zeal of the sixteenth century had spent its force and been succeeded by the universal conviction of the reflecting believer that Christianity is much more than an institution based upon a verifiable historical revelation, that it is, in fact, a revelation in the philosophical meaning, an interpretation of human and divine nature. We only understand Pascal when we see that his religion is not ordinary piety or superstition, but profound philosophy.

Let us now look at the man himself. $\mathrm{He}$ is a younger contemporary of Galileo and Descartes. He survived both, but died before Malebranche or Spinoza had begun to write. This is peculiarly significant in appreciating his attitude towards the Cartesian philosophy, for Malebranche developed that doctrine along Augustinian lines, which may have been actually suggested by Pascal's writings. The illustration of le ciron to explain the relativity of magnitudes, expounded by Malebranche in the "Recherche de la Vérité," seems taken directly from a well-known passage in Pascal's "Pensées."

Pascal agreed with Descartes in his doctrine of the soul, or thinking substance, with its corollary that the animals are automata, but he was revolted by the "Principia" and its claim to be able to explain the world by "figure and movement." "Quand cela serait vrai," he says, "nous n'estimons pas que toute la philosophie vaille une heure de peine." Notwithstanding his keen enjoyment of mathematical problems and his intense interest in physical experiments, the 
whole value of philosophy for him lay in the light it shed on moral problems, and on the power it gave man to interpret the Christian revelation. His point of view, while it accepts the principles of Descartes's philosophy, applies them in a way which makes his doctrine its very antithesis.

Descartes was shown the Treatise on Conic Sections which Pascal composed when sixteen, and refused to believe in its originality. He thought it the work of Desargues, from whom indeed Pascal had learnt much, but Desargues himself acknowledged the originality of Pascal's treatise in its essential points. In 1647 Descartes paid two visits to Pascal, who had come to Paris with his sister Jacqueline for medical advice. Jacqueline has given an account of their meeting in a letter to her sister Gilberte Périer. They discussed the question of the void. Torricelli, the pupil of Galileo, had demonstrated the phenomenon of atmospheric pressure by the famous invention of the barometer, inverting a column of mercury in a glass tube closed at one end, with the other end immersed in an open mercury bath, and then measuring the height of the column.

This was of course the crucial experiment, but there still remained considerable doubt as to its interpretation. To many, including Torricelli himself, it was merely a case in point of the old principle that nature abhors a vacuum. Descartes had rejected this principle on a priori grounds. Pascal explained to Descartes his theory of an ocean of air, at the bottom of which we were situated, and assumed that like all fluids it would maintain an equilibrium, and reasoned that above every point of the earth's surface was a column pressing down on us, the weight of which would vary with the altitude. He had already made experiments to prove this on a tower in Rouen, and he now proposed to carry out an experiment on a large scale on the Puy de Dôme in Auvergne. Descartes discussed it with great interest and confidently foretold its success. The experiment was carried out by the aid of Pascal's brother-in-law, M. Périer, with the result that the time-honoured, firmly established principle of the abhorrence of a vacuum passed into limbo.

Pascal's life divides naturally into three periods. To the first belong the mathematical works and the physical experiments, to the second the literary achievement of the "Lettres Provinciales," and to the third the philosophical and mystical "Pensées." In all of them his great genius is manifest, and he might easily have been one of those master minds which determine the direction of human thought. In science and philosophy he showed an intellectual power and incentive. which places him on a level with Descartes and Galileo, yet he stands alone, grand but solitary, in the great intellectual movement of humanity. It was more than a religious act, it was typical of his whole intellectual position, when he joined the solitaires of Port Royal. We may count his unworldliness as loss or as gain, but he sacrificed for it alike scientific and philosophic leadership. The tragedy is that the Christian Church did not value what he gave to her when he renounced the world.

The works by which Pascal has immortalised himself are "Les Lettres Provinciales" and "Les Pensées." His mathematical works, like his arithmetical machine which took three years to perfect and is preserved at the Conservatoire des Arts et Métiers in Paris, are valuable for the evidence they afford of the nature of his genius rather than for their originality of discovery, but the two great literary works have been read in innumerable successive editions. Yet strangely enough both are valued and cherished for what to Pascal himself was purely adventitious and no part of the original design. The "Provinciales" are classical on account of their attack on the Jesuits and for the exposure of Jesuit casuistry. The world has little interest to-day in the Jansenist doctrine, which it was the main purpose of the letters to expound and to defend. Were it not for Pascal, the very names of Jansenius and Molina would scarcely be known outside narrow theological circles. The doctrine of sufficient grace has little more than antiquarian interest for students, but for Pascal it was the rationalising of Christian doctrine, the philosophy of a religion of redemption as distinct from the institution of sacraments and formularies founded on it:

The "Lettres Provinciales" had an immediate success, but it is unlikely that they would have accomplished their design, or have afforded even a temporary cessation of the Jesuit hostility against the theologians of Port Royal, but for an event of an altogether different nature, and one which had a powerful influence on Pascal himself. This is what is known as the miracle of the sacred thorn. Pascal's niece, Marguérite Périer, was a pensionnaire at Port Royal, and the little girl suffered from an abscess of the lachrymal gland, which discharged into the eye and into the nose, causing her inconvenience and suffering. Medical treatment had proved wholly ineffective, but after having touched the spot one day with the relic of the sacred thorn, exposed for adoration on the altar, she was completely cured. The doctors certified that "la guérison surpassait les forces ordinaires de la nature," and the miracle was solemnly attested by the vicars-general of the Archbishopric of Paris.

"Les Pensées" was not designed by Pascal for publication in any form whatever. When he died a disordered mass of papers containing his written notes was found. They were unconnected, casual, jottings on odd bits of paper, many being incompleted sentences. It was known that Pascal had had in mind to write an "Apology" of Christianity, a defence against atheistical arguments. The editors took this as the clue to the arrangement of the fragments, and Arnauld; Nicole, and other leaders of Port Royal, after the "peace of the church," which restored them to their monastery in 1669 , published the first edition of the "Pensées." Few books have had such a success. Edition has followed edition through the succeeding centuries. The original fragmentary notes still exist, and scholars may now study them in the "Reproduction en phototypie du manuscrit des Pensées de Blaise Pascal," published by Monsieur Léon Brunschvicg.

Such was the marvellous genius, the tercentenary of whose birth is being celebrated this year in his native city, Clermont, and at the scene of his activities, Port Royal des Champs, near Paris.

NO. 2798 , VOL. I I 1$]$ 